\title{
Merkel Cell Carcinoma with Spontaneous Regression: A Case Report and Immunohistochemical Study
}

\author{
Hitoshi Terui ${ }^{a, b} \quad$ Taku Fujimura $^{a} \quad$ Aya Kakizaki $^{a} \quad$ Sadanori Furudate $^{a}$ \\ Setsuya Aiba ${ }^{a}$ \\ ${ }^{a}$ Department of Dermatology, Tohoku University Graduate School of Medicine, and \\ ${ }^{b}$ Department of Dermatology, Sendai City Hospital, Sendai, Japan
}

\section{Key Words}

Merkel cell carcinoma · Spontaneous regression · Granulysin · Tumor-associated macrophages

\begin{abstract}
Merkel cell carcinoma (MCC) is an aggressive neuroendocrine carcinoma that only rarely regresses spontaneously. Since little is known about the immunological mechanisms involved in the spontaneous regression of MCC, we describe a case of MCC with spontaneous regression and employed immunohistochemical staining for cytotoxic and immunosuppressive molecules to investigate possible mechanisms involved in the spontaneous regression of MCC. Interestingly, compared to conventional MCC, tumor-infiltrating lymphocytes in MCC with spontaneous regression contained higher numbers of $\mathrm{CD} 8^{+}$cells and granulysin-bearing cells and lower numbers of $\mathrm{CD}_{206}{ }^{+}$cells. Our present study suggests one of the possible reasons for the spontaneous regression of MCC.

(C) 2016 The Author(s)

Published by S. Karger AG, Basel
\end{abstract}

\section{Introduction}

Merkel cell carcinoma (MCC) is an aggressive, cutaneous, neuroendocrine carcinoma that originates from either Merkel cells or from pluripotent stem cells in the basal layer of the epidermis [1, 2]. MCC can spontaneously regress [3-5], although such cases are extremely rare. Recent reports suggested that the type of tumor-infiltrating leukocytes (TILs) could

\section{KARGER}

Taku Fujimura

Department of Dermatology

Tohoku University Graduate School of Medicine

Seiryo-machi 1-1, Aoba-ku, Sendai, Miyagi 980-8574 (Japan)

E-Mail tfujimura1@mac.com 
Terui et al:: Merkel Cell Carcinoma with Spontaneous Regression: A Case Report and Immunohistochemical Study

determine the prognosis and tumor-specific survival of MCC [6-8]. Therefore, in this report, we employed immunohistochemical staining for cytotoxic and immunosuppressive molecules to investigate the possible mechanisms involved in the spontaneous regression of MCC.

\section{Case Presentation}

A 94-year-old Japanese woman visited our outpatient clinic with a 2-month history of a tumor on her left cheek. On her initial visit, physical examination revealed a red-colored, elastic, soft, well-demarcated nodule on her left cheek (fig. 1a). The size of the tumor was of approximately $22 \times 20 \mathrm{~mm}$ in diameter. A biopsy specimen from her cheek revealed sheets of small cells with hyperchromatic nuclei extending throughout the dermis with prominent leukocytes (fig. 2a). Immunohistochemical staining revealed that these atypical cells were positive for CK20, synaptophysin (fig. 2b) and neuron-specific enolase, and negative for chromogranin A, thyroid transcription factor 1, S-100, Melan-A and HMB-45. From the above findings, we diagnosed this case as MCC. Surprisingly, the tumor spontaneously regressed 20 days after the biopsy (fig. 1 b).

To further investigate the possible mechanisms in the spontaneous regression, we employed immunohistochemical staining of CD8 (fig. 3a), CD163, CD206, Foxp3, granulysin (fig. $3 \mathrm{~b}$ ) and caspase 3 (fig. 3c) for the present case and 5 cases of conventional MCC. We counted the number of immunoreactive cells, using an ocular grid of $1 \mathrm{~cm}^{2}$ at a magnification of $\times 400$. In the present case, the number of $\mathrm{CD}^{+}$cells, granulysin-bearing cells and caspase $3^{+}$cells tended to be higher than in conventional MCC cases (fig. 4). In contrast, the number of $\mathrm{CD}_{206}{ }^{+}$cells tended to be lower than in conventional MCC cases. There was no difference in the number of $\mathrm{CD} 163^{+}$and Foxp3+ cells between these groups.

\section{Discussion}

Previous reports suggested the importance of evaluating the tumor microenvironment in the lesional skin of MCC. Indeed, Paulson et al. [6] reported an association between the infiltration of intratumoral CD8+ lymphocytes and improved MCC-specific survival. Notably, $\mathrm{CD}^{+}$cells contain various subpopulations of cytotoxic $\mathrm{T}$ cells, including granulysin-bearing cells. Granulysin has homology to other cytotoxic molecules of the saponin-like protein family [9] and lyses various tumors, which might be related to the prognosis of cancer patients and the self-regression of tumors [10-13].

In the present case, compared to the 5 cases of conventional MCC, the numbers of CD8 ${ }^{+}$ cells, granulysin-bearing cells and caspase $3^{+}$cells were higher. In addition, a recent report also suggested the significance of the expression of PD-1 on TILs [3]. These observations suggested that the anti-tumor immune reaction in MCC might mainly correlate with cytotoxic T cells.

Concerning tumor-associated macrophages (TAMs), in contrast to cytotoxic T cells, there was no difference in the numbers of immunosuppressive cells (CD163+ TAMs and Foxp $3^{+}$regulatory $\mathrm{T}$ cells) between MCC with or without spontaneous regression. Since there was no difference of the numbers of $\mathrm{CD} 163^{+}$cells in each group, to assess the expression of M2 markers, such as CD206, on TAMs is important [14, 15]. Indeed, the number of $\mathrm{CD}^{206^{+}}$cells, which could be one of the markers for M2 macrophages, was lower in MCC with spontaneous regression. Notably, M2-polarized TAMs produce various chemokines that recruit TILs to maintain the immunosuppressive tumor microenvironment $[16,17]$. In ag- 
Terui et al.: Merkel Cell Carcinoma with Spontaneous Regression: A Case Report and Immunohistochemical Study

gregate, a lower number of CD206+ TAMs might correlate with the increased number of cytotoxic $\mathrm{T}$ cells in the present case.

In this report, we described a case of MCC with spontaneous regression and employed immunohistochemical staining for cytotoxic and immunosuppressive molecules to investigate the possible mechanisms in the spontaneous regression of MCC. Since this report presents a single case of MCC with spontaneous regression, further analysis of the mechanisms underlying this phenomenon may provide fundamental insights into the mechanisms of cytotoxic T cells and TAMs in the spontaneous regression of MCC. Such issues will need to be clarified in future investigations.

\section{Statement of Ethics}

The patient gave written informed consent.

\section{Disclosure Statement}

The authors declare no conflicts of interest.

\section{References}

1 Ferringer T, Rogers HC, Metcalf JS: Merkel cell carcinoma in situ. J Cutan Pathol 2005;32:162-165.

-2 Van Keymeulen A, Mascre G, Youseff KK, Harel I, Michaux C, De Geest N, Szpalski C, Achouri Y, Bloch W, Hassan BA, Blanpain C: Epidermal progenitors give rise to Merkel cells during embryonic development and adult homeostasis. J Cell Biol 2009;187:91-100.

-3 Fujimoto N, Nakanishi G, Kabuto M, Nakano T, Eto H, Nakajima H, Sano S, Tanaka T: Merkel cell carcinoma showing regression after biopsy: evaluation of programmed cell death 1-positive cells. J Dermatol 2015;42:496-499.

4 Kayashima K, Ono T, Johno M, Kojo Y, Yamashita N, Matsunaga W: Spontaneous regression in Merkel cell (neuroendocrine) carcinoma of the skin. Arch Dermatol 1991;127:550-553.

5 Duncan WC, Tschen JA: Spontaneous regression of Merkel cell (neuroendocrine) carcinoma of the skin. J Am Acad Dermatol 1993;29:653-654.

6 Paulson KG, Iyer JG, Tegeder AR, et al: Transcriptome-wide studies of Merkel cell carcinoma and validation of intratumoral CD8+ lymphocyte invasion as an independent predictor of survival. J Clin Oncol 2011;29:1539-1546.

7 Dowlatshahi M, Huang V, Gehad AE, et al: Tumor-specific T cells in human Merkel cell carcinomas: a possible role for Tregs and T-cell exhaustion in reducing T-cell responses. J Invest Dermatol 2013;133:1879-1889.

8 Asgari MM, Sokil MM, Warton EM, et al: Effect of host, tumor, diagnostic, and treatment variables on outcomes in a large cohort with Merkel cell carcinoma. JAMA Dermatol 2014;150:716-723.

-9 Krensky AM, Clayberger C: Granulysin: a novel host defense molecule. Am J Transplant 2005;5:1789-1792.

10 Pagès F, Berger A, Camus M, Sanchez-Cabo F, Costes A, Molidor R, Mlecnik B, Kirilovsky A, Nilsson M, Damotte D, Meatchi T, Bruneval P, Cugnenc PH, Trajanoski Z, Fridman WH, Galon J: Effector memory T cells, early metastasis, and survival in colorectal cancer. N Engl J Med 2005;353:2654-2666.

11 Kambayashi Y, Fujimura T, Furudate S, Hashimoto A, Haga T, Aiba S: Comparison of immunosuppressive cells and cytotoxic cells in angiosarcoma: the development of a possible supportive therapy for angiosarcoma. Dermatology 2013;227:14-20.

-12 Furudate S, Fujimura T, Kambayashi Y, Kawano M, Ogasawara K, Tsukada A, Tamabuchi E, Haga T, Hashimoto A, Aiba S: Successful treatment of adult onset Langerhans cell histiocytosis with bi-weekly administration of pegylated interferon- $\alpha$. Acta Derm Venereol 2014;94:611-612.

13 Furudate S, Fujimura T, Tsukada A, Numata Y, Kambayashi Y, Aiba S: Profiles of tumor-infiltrating lymphocytes in a case of trichilemmal carcinoma with spontaneous regression. Case Rep Dermatol 2012;4:215-221. 


\section{Case Reports in Dermatology}

\begin{tabular}{l|l}
\hline Case Rep Dermatol 2016;8:52-58 \\
\hline DOI: $10.1159 / 000444317$ & $\begin{array}{l}\text { (c) 2016 The Author(s). Published by S. Karger AG, Basel } \\
\text { www.karger.com/cde }\end{array}$ \\
\hline
\end{tabular}

Terui et al:: Merkel Cell Carcinoma with Spontaneous Regression: A Case Report and Immunohistochemical Study

14 Kambayashi Y, Fujimura T, Furudate S, Asano M, Kakizaki A, Aiba S: The possible interaction between receptor activator of nuclear factor kappa-B ligand (RANKL) expressed by extramammary Paget cells and its ligand on dermal macrophages. J Invest Dermatol 2015;135:2547-2550.

-15 Kakizaki A, Fujimura T, Kambayashi Y, Furudate S, Kawano M, Ogasawara K, Aiba S: Comparison of CD163+ macrophages and CD206+ cells in lesional skin of CD30+ lymphoproliferative disorders of lymphomatoid papulosis and primary cutaneous anaplastic large-cell lymphoma. Acta Derm Venereol 2015;95:600-602.

-16 Fujimura T, Kambayashi Y, Furudate S, Asano M, Kakizaki A, Aiba S: Receptor activator of nuclear factor kappa-B ligand (RANKL) promotes the production of CCL17 from RANK+ M2 macrophages. J Invest Dermatol 2015;135:2884-2887.

-17 Fujimura T, Kambayashi Y, Furudate S, Kakizaki A, Aiba S: Immunomodulatory effect of bisphosphonate risedronate sodium on $\mathrm{CD} 163^{+}$arginase $1^{+} \mathrm{M} 2$ macrophages: the development of a possible supportive therapy for angiosarcoma. Clin Dev Immunol 2013;2013:325412.
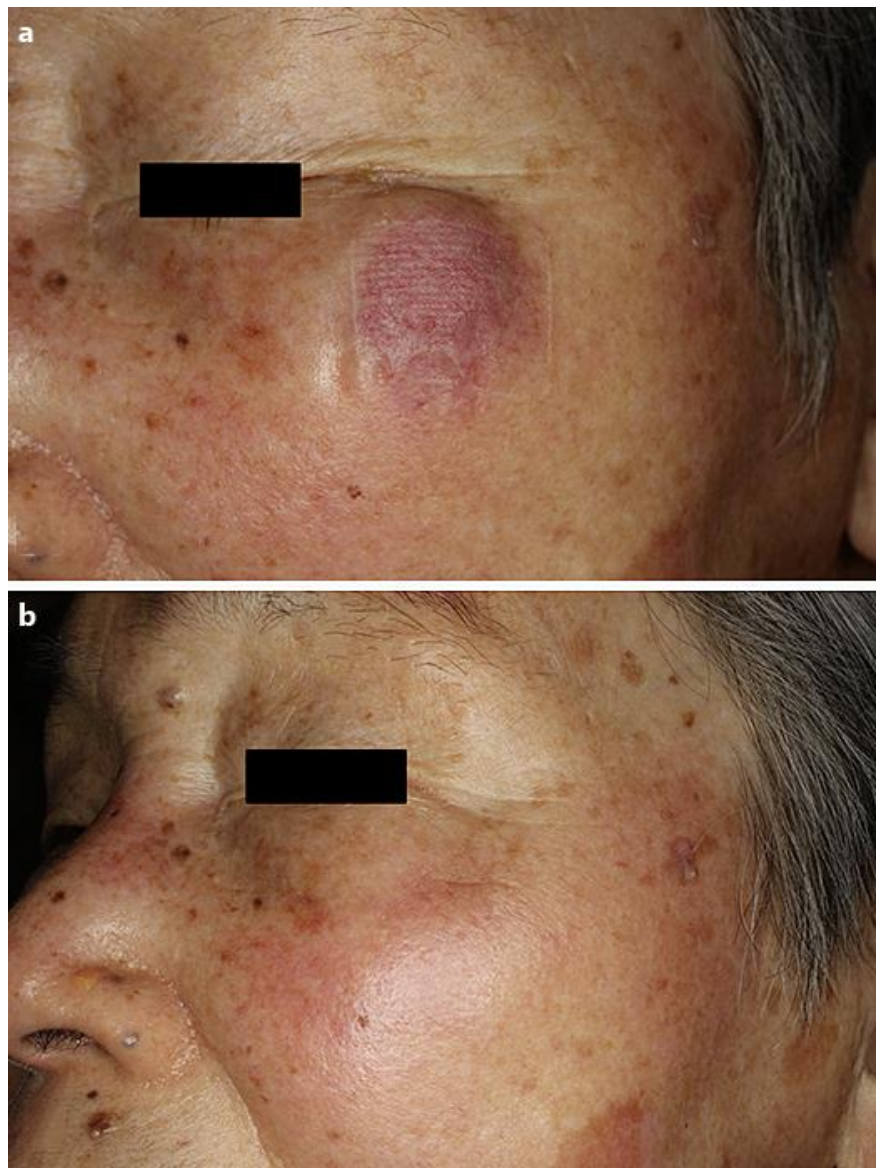

Fig. 1. a A red-colored, elastic, soft, well-demarcated nodule on the left cheek. $\mathbf{b}$ The tumor spontaneously regressed 20 days after the biopsy. 
Terui et al.: Merkel Cell Carcinoma with Spontaneous Regression: A Case Report and Immunohistochemical Study
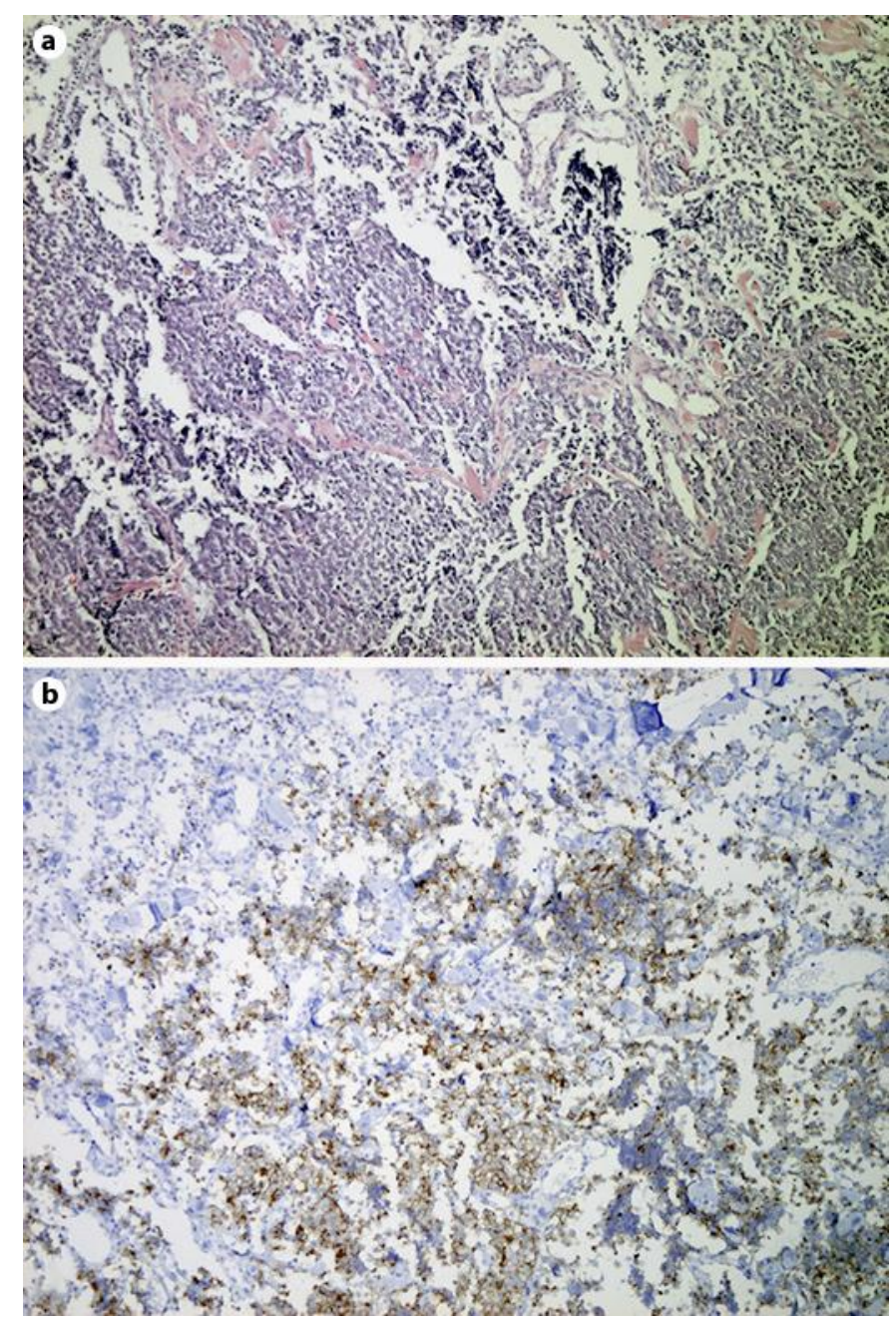

Fig. 2. a Sheets of small cells with hyperchromatic nuclei extending throughout the dermis with prominent leukocytes. b Paraffin-embedded tissue samples were deparaffinized and stained with antisynaptophysin antibodies. The sections were developed with 3,3'-diaminobenzidine tetrahydrochloride (original magnification $\times 100$ ) . 
Terui et al.: Merkel Cell Carcinoma with Spontaneous Regression: A Case Report and Immunohistochemical Study
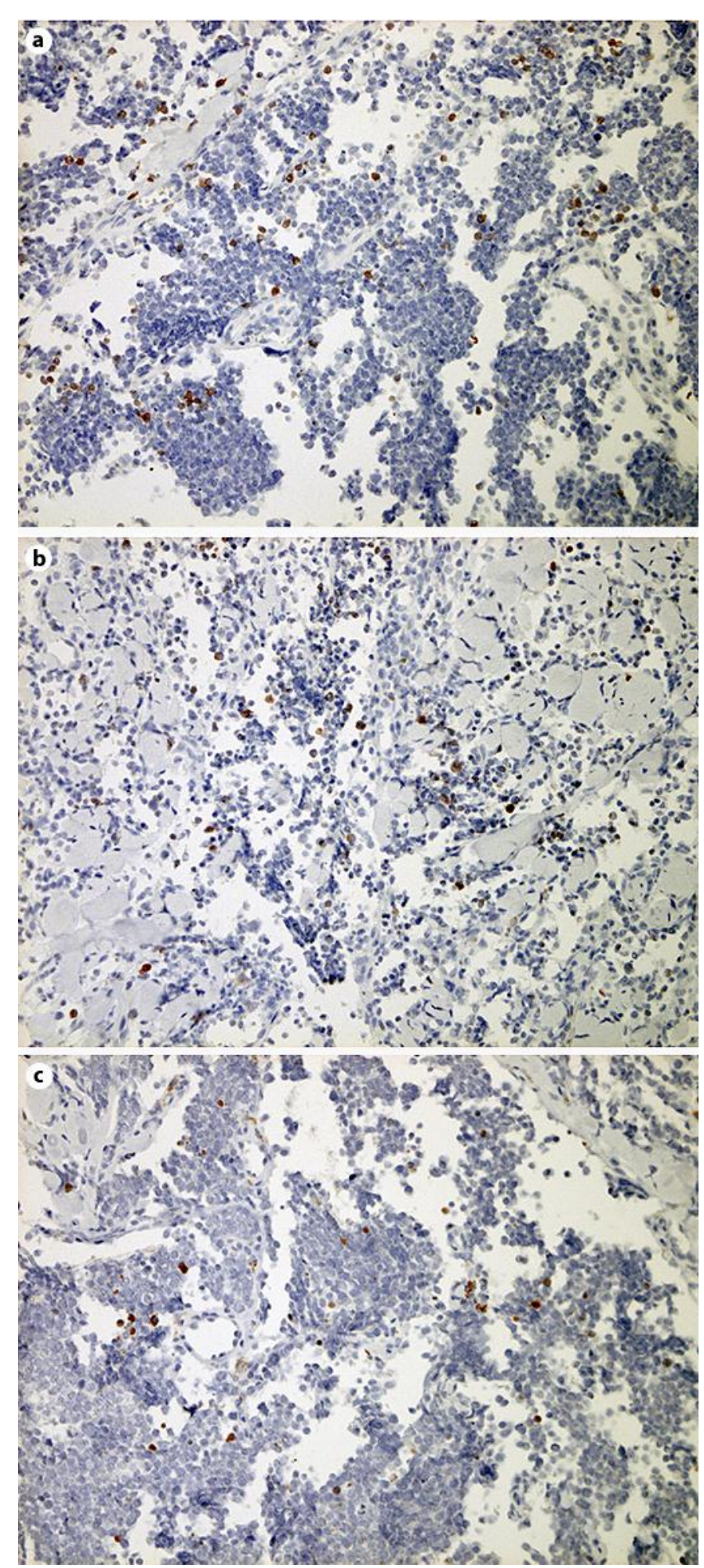

Fig. 3. Paraffin-embedded tissue samples were deparaffinized and stained with anti-CD8 antibodies (a), anti-granulysin antibodies (b), and anti-caspase 3 antibodies (c). The sections were developed with Liquid Permanent Red (original magnification $\times 100$ ). 


\section{Case Reports in Dermatology}

Terui et al.: Merkel Cell Carcinoma with Spontaneous Regression: A Case Report and Immunohistochemical Study

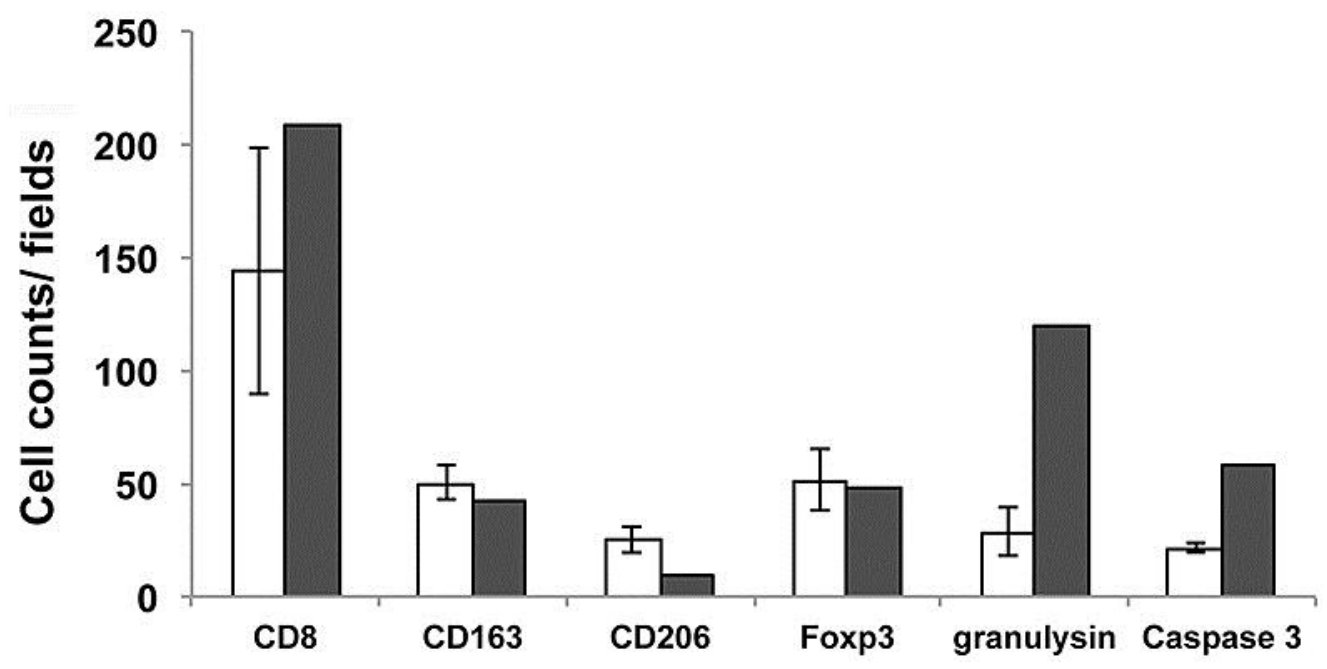

Fig. 4. Summary of the average number of immunoreactive cells in the 5 conventional MCC cases and the present case. Three representative fields of each section were selected from tumor areas with dense dermal lymphoid infiltrates. The number of immunoreactive cells was counted using an ocular grid of $1 \mathrm{~cm}^{2}$ at a magnification of $\times 400$. The data are expressed as the means \pm SD of the numbers in each area. White bars: conventional MCC; black bars: present case. 